\title{
The role of clothing in thermal comfort: how people dress in a temperate and humid climate in Brazil
}

\author{
O papel da vestimenta no conforto térmico: como as \\ pessoas se vestem em um clima temperado e úmido \\ brasileiro
}

\section{Renata De Vecchi \\ Roberto Lamberts Christhina Maria Candido}

\begin{abstract}
$\mathbf{T}$

hermal insulation from clothing is one of the most important input variables used to predict the thermal comfort of a building's occupants. This paper investigates the clothing pattern in buildings with different configurations located in a temperate and humid climate in Brazil.
\end{abstract}

Occupants of two kinds of buildings (three offices and two university classrooms) assessed their thermal environment through 'right-here-right-now' questionnaires, while at the same time indoor climatic measurements were carried out in situ (air temperature and radiant temperature, air speed and humidity). A total of 5,036 votes from 1,161 occupants were collected. Results suggest that the clothing values adopted by occupants inside buildings were influenced by: 1) climate and seasons of the year; 2) different configurations and indoor thermal conditions; and 3) occupants' age and gender. Significant intergenerational and gender differences were found, which might be explained by differences in metabolic rates and fashion. The results also indicate that there is a great opportunity to exceed the clothing interval of the thermal comfort zones proposed by international standards such as ASHRAE 55 (2013) - 0.5 to 1.0 clo - and thereby save energy from cooling and heating systems, without compromising the occupants' indoor thermal comfort.

Keywords: Thermal comfort. Clo insulation. Temperate and humid climate.

\section{Resumo}

Renata De Vecchi Universidade Federal de Santa Catarina

Florianópolis - SC - Brasil

Roberto Lamberts Universidade Federal de Santa Catarina Florianópolis - SC - Brasil

Christhina Maria Candido The University of Sydney Sydney - Austrália

Recebido em 15/03/16 Aceito em 12/08/16
O isolamento térmico da vestimenta é uma das variáveis de entrada mais importantes utilizadas para prever o conforto térmico dos ocupantes dentro das edificações. Este artigo investiga padrões de vestimenta em edifícios com diferentes configurações localizados em um clima temperado e úmido brasileiro. Ocupantes de dois tipos de edifícios (três escritórios e duas salas de aula universitárias) avaliaram seu ambiente térmico através de questionários simultaneamente às medições microclimáticas internas in situ (temperatura do ar e radiante média, velocidade e umidade do ar). Um total de 5.036 votos provenientes de 1.161 ocupantes foram coletados. Os resultados encontrados sugerem que a vestimenta adotada pelos ocupantes nas edificações analisadas é influenciada por: 1) clima e pelas estações do ano; 2) configurações e condições térmicas internas; e 3) idade e gênero dos ocupantes. Diferenças significativas entre gerações e gêneros foram encontradas, o que provavelmente se explica pelas diferenças na taxa metabólica e moda local. Os resultados também indicaram que há uma grande oportunidade de exceder o intervalo de vestimenta determinado por normas internacionais como a ASHRAE 55 (2013) de 0,5 a 1,0 clo para as zonas de conforto térmico, impactando positivamente no dispêndio de energia voltada ao resfriamento e aquecimento artificial, sem, no entanto, comprometer o conforto térmico dos seus ocupantes em espaços internos.

Palavras-chaves: Conforto térmico. Isolamento da vestimenta (clo). Clima temperado e úmido. 


\section{Introduction}

Thermal insulation from clothing is one of the most important input variables used to predict occupants' indoor thermal comfort (AMERICAN..., 2013a). In both of the most common and current thermal comfort standards, clothing is an imperative protagonist. It represents one of the six variables used to calculated PMV/PPD in the static approach (FANGER, 1970), and for the adaptive method, clothing insulation worn inside buildings is considered as a key feature of the occupants adaptation, strongly dependent on both mean indoor and outdoor temperatures (DE DEAR; BRAGER; COOPER, 1997).

As a personal factor, the amount of clothing that people wear inside buildings is highly bound to human subjectivity, also involving important factors such as climate, culture and local fashion (HAVENITH; HOLMÉR; PARSONS, 2002; MORGAN; DE DEAR, 2003; CHUN et al., 2008; KWON; CHOI, 2012; SCHIAVON; LEE, 2013). Within the range of opportunities that occupants make use of strategies to adapt and optimize their thermal sensation, the first and most immediate one - perhaps even an unconscious one - is the clothing adjustment by removing a garment when they feel warm, or adding another layer when feeling cool.

Even though the importance of clothing on thermal comfort evaluation is recognized, not many papers presented results focusing on the subjectivity of clothing insulation. Nevertheless, some studies discussed the neglected factors on clothing calculation (HAVENITH; HOLMÉR; PARSONS, 2002), the variance of clothing insulation across the seasons in Korean (KWON; CHOI, 2012) and the impact of cooling strategies on thermal comfort factors from air-conditioning and naturally ventilated office populations in Thailand. Based in ASHRAE RP-884 database, two studies were performed connecting dynamic models to predict clothing insulation - which was subsequently adopted by ASHRAE 55 Standard (AMERICAN..., 2013a) - and also people's clothing behavior as a function of external and internal temperature (outside, mean weekly outside and internal temperatures); further including Singapore and Indonesia data (DE CARLI et al., 2007; SCHIAVON; LEE, 2013). Type of industry, gender and indoor settings have also been investigated by Morgan and de Dear (2003), and the energy conservation potential due to flexible dress-code such as the Super Cool Biz initiative in Japan was discussed by Indraganti, Ooka and Rijal
(2013) and Tanabe, Iwahashi and Tsushima (2012).

In Brazil, most of thermal comfort field studies was performed in urban outdoor environments (KRÜGER; ROSSI, 2011; LABAKI et al., 2012; MONTEIRO; ALUCCI, 2012; ROSSI; KRÜGER; BRÖDE, 2012), whereas very few indoor thermal comfort studies have been carried out. The few existing databases comprise data from field experiments conducted in school and university buildings (XAVIER; LAMBERTS, 2000; LAZAROTTO; SANTOS, 2007; CÂNDIDO et al., 2010, 2011; DE VECCHI; CÂNDIDO; LAMBERTS, 2016), and one in military and commercial buildings (ANDREASI; LAMBERTS; CÂNDIDO, 2010). However, none of them focused on key factors influencing garments worn by people indoors which is an oversight considering the vast climatic variability observed in Brazil. This paper aims to shed some light on this field by investigating the impact of subjects' age and gender on clo values worn by people in mixed-mode and air-conditioning buildings located in a temperate and humid climate.

\section{Method}

A total of 5,036 right-here-right-now questionnaires were collected from 1,161 subjects during field experiments from three buildings located in Florianópolis - Brazil:

(a) a fully air-conditioned commercial building (type 1);

(b) two mixed-mode government buildings (type

2), both from De Vecchi (2015); and

(c) university classroom with a mixed-mode system (type 3) from De Vecchi (2011).

Florianópolis is a capital city located in the coast of Santa Catarina state, south area of Brazil (latitude $\left.27^{\circ} 40^{\prime} \mathrm{S}\right)$. According to Köppen's classification, the city is represented by a temperate and humid climate, with external temperatures varying from 17 to $29^{\circ} \mathrm{C}$ during the summer and spring time, 13 to $22^{\circ} \mathrm{C}$ during the autumn and winter (GOULART; LAMBERTS; FIRMINO, 1998). Relative humidity is high throughout the year (minimum monthly average is $80 \%$ in November and maximum monthly average is $84 \%$ in July) and there is no dry season. The highest rainfall occurs from January to March, and the lowest from July to August (mean annual precipitation is $1,521 \mathrm{~mm}$ ). There is a higher prevalence in winds in the northern direction, followed by the southern direction. 
The field studies were conducted during all four different seasons. Details about the external air temperatures during the measurements, the related seasons and building type are summarized on Table 1 and 2 below. The external data was acquired from a meteorological station located at the campus (Laboratory of Energy Conversion Engineering Technology - LEPTEN/UFSC), which provides data to the World Meteorological Organization (WMO).

Table 1 - Outdoor air temperature $\left({ }^{\circ} \mathrm{C}\right)$ over the days of field measurements according with the seasons

\begin{tabular}{l|c|c|c|c}
\hline \multirow{2}{*}{ Season } & \multicolumn{3}{|c|}{ External Air Temperature } & \\
\cline { 2 - 4 } & Max. & Min. & Mean & n \\
\hline Spring & 26.3 & 17.8 & 21.5 & 833 \\
Summer & 28.7 & 23.2 & 26.7 & 466 \\
Autumn & 25.2 & 19.0 & 22.3 & 2355 \\
Winter & 22.1 & 12.2 & 17.8 & 1382 \\
\hline \multicolumn{4}{|c|}{ Total } & $\mathbf{5 0 3 6}$ \\
\hline
\end{tabular}

Table 2 - Buildings investigated during field experiments

\begin{tabular}{|c|c|c|c|c|c|c|}
\hline \multirow[b]{2}{*}{ Building } & \multirow[b]{2}{*}{ Type } & \multirow{2}{*}{$\begin{array}{c}\text { Total number of } \\
\text { observations } \\
\text { (votes) }\end{array}$} & \multirow{2}{*}{$\begin{array}{l}\text { Cooling } \\
\text { system }\end{array}$} & \multicolumn{2}{|c|}{ Clo } & \multirow[b]{2}{*}{ Adaptive opportunities } \\
\hline & & & & Min & Max & \\
\hline Type 1 & $\begin{array}{l}\text { Private } \\
\text { Office }\end{array}$ & 1,274 & HVAC & 0.42 & 1.40 & $\begin{array}{l}\text { No operable windows, } \\
\text { informal "business dress } \\
\text { code", no personal control is } \\
\text { available. }\end{array}$ \\
\hline Type 2 & $\begin{array}{l}\text { Private } \\
\text { Office }\end{array}$ & 1,471 & $\begin{array}{l}\text { Mixed- } \\
\text { mode }\end{array}$ & 0.31 & 1.49 & $\begin{array}{l}\text { Operable windows, informal } \\
\text { "business dress code", } \\
\text { occupants are allowed to } \\
\text { switch on/off air } \\
\text { conditioning }\end{array}$ \\
\hline Type 3 & $\begin{array}{c}\text { Classro } \\
\text { om }\end{array}$ & 2,291 & $\begin{array}{c}\text { Mixed- } \\
\text { mode }\end{array}$ & 0.29 & 0.90 & $\begin{array}{l}\text { Operable windows, ceiling } \\
\text { fans, no dress code, } \\
\text { occupants are allowed to } \\
\text { switch on/off air } \\
\text { conditioning }\end{array}$ \\
\hline
\end{tabular}

Simultaneous air temperature, humidity, globe temperature and air speed measurements were carried-out with laboratory precision using a microclimatic station named SENSU ${ }^{1}$ located in the center of the room $(0.60 \mathrm{~m}$ from the floor). Measurements were taken continuously while subjects answered a thermal comfort questionnaire (paper questionnaires in classrooms and via electronic software in office environment). Individualized air speed readings were also taken from the occupied zone for each subject, using a handheld hot-wire anemometer sensor ${ }^{2}$. Questionnaire items asked subjects to assess their

${ }^{1} \mathrm{SENSU}$ is a microclimatic station developed by a laboratory specialized in measurement sensors and thermal phenomena (Laboratory of Porous Media and Thermo Physical Properties) at UFSC.

${ }^{2}$ Omnidirectional air speed sensor was also developed by the same laboratory, and works under the same principle of the air speed sensor from SENSU. thermal environment on right-here-right-now basis and it featured classic thermal sensation, preference and acceptability questions, air movement acceptability and preference, prior exposure to air-conditioning and cooling preference. For the purpose of this paper, only the question regarding thermal comfort was used for further analysis (right now, is this environment thermally comfortable for you?). Anthropometric characteristics (gender and age) were also collected by means of questionnaires fully filled by the occupants. Each subject stayed inside the building and answered the questionnaire approximately five times throughout a 140-minute survey period (the participation was completely voluntary, and the occupants were aware of the entire protocol before starting the questionnaire). Full details about the whole study and the 
complete version of the questionnaire can be found in De Vecchi $(2011,2015)$.

Subjects were also asked to select the garment items they were wearing from a standardized checklist (Table 3) based in ASHRAE 55 (AMERICAN..., 2013a) just before the beginning on experiments. It is important to highlight that according with the ASHRAE Handbook Fundamentals (AMERICAN..., 2013b)), the clochecklist method can represent a $\pm 25 \%$ error in the clothing insulation value, which is a common consequence of most real field studies in all over the world. Thereat, it was assumed that if any error exists in the sample, they are uniformly distributed and represents a low impact in the final comparisons. The changes in the occupants' clothing layers were monitored through questionnaires and site observations registered by the researchers.

The clothing ranges found in each type of buildings were depicted on Table 2 above. It was automatically assumed that all participants were using underwear (briefs for men and panties and bra for women, corresponding to 0.04 clo for both of them). Also, clothing estimates included the incremental effect of the upholstered chair upon which the subject was sitting at the time of the questionnaire -0.10 clo for a standard office chair in classrooms settings and 0.15 clo representing an executive chair in the office settings.
Operative temperature was calculated in accordance with normative appendix A from ASHRAE 55 (AMERICAN..., 2013a), and statistical analysis was performed using IBM SPSS software (Statistical Package for the Social Sciences - SPSS Inc., Chicago, IL, USA; 22.0 version).

\section{Results and discussion}

For the purpose of this paper, analysis focused on subjects' clothing insulation and its variations observed during seasons, operative temperature values recorded indoors, type of buildings and also subjects' age and gender. Figure 1 shows a distribution of the calculated operative temperature during the site observations and Figure 2 shows the frequency of collected data according to the seasons. In Figure 1, the calculated range of operative temperature varies between $21^{\circ} \mathrm{C}$ and $28^{\circ} \mathrm{C}$. The main sample is slightly concentrated in autumn $(47 \%)$ followed by winter $(27 \%)$, spring $(17 \%)$ and summer (9\%).

Table 4 summarizes the subjects' age profile broken down per building type investigated. Type 1 and 2 buildings show a slightly higher concentration of occupants in the middle age group range $(31 \leq$ age $\leq 50)$. Type 3 building hosts a majority of young occupants (age $\leq 30$ ) and a reasonable balance between females and males is observed.

Table 3 - Garment insulation used in the questionnaire

\begin{tabular}{l|c|l|c}
\hline \multicolumn{1}{c|}{ Garment 1 Peça de roupa } & $\mathrm{I}_{\mathrm{cl}}$ & \multicolumn{1}{c|}{ Garment 1 Peça de roupa } & $\mathrm{I}_{\mathrm{cl}}$ \\
\hline$\square$ Shirt/Polo Shirt 1 Camiseta/Camisa Polo & 0.17 & $\square$ Short skirt (thin) 1 Saia curta (joelho) & 0.14 \\
\hline$\square$ Short-sleeved shirt 1 Camisa manga curta & 0.19 & $\square$ Long skirt (thin) 1 Saia longa (canela) & 0.23 \\
\hline$\square$ Long-sleeve shirt 1 Camisa manga longa & 0.25 & $\square$ Shorts/walking Shorts 1 Shorts/Bermuda & 0.08 \\
\hline$\square$ Long-sleeve sweater 1 Suéter manga longa & 0.25 & $\square$ Short-sleeve shirtdress 1 Vestido Social & 0.29 \\
\hline $\begin{array}{l}\square \text { Short-sleeve sweater 1 } \\
\text { Suéter manga curta }\end{array}$ & 0.36 & $\square$ Coveralls 1 Macacão & 0.49 \\
\hline $\begin{array}{l}\square \text { Thin jacket/Single-breasted } \\
\text { Jaquela/Paletó Fino }\end{array}$ & 0.42 & $\square$ Panty hose 1 Meia-calça & 0.04 \\
\hline $\begin{array}{l}\square \text { Thick jacket/Single-breasted } \\
\text { Jaquela/Paletó grosso }\end{array}$ & 0.44 & $\square$ Knee socks 1 Meia soquete & 0.06 \\
\hline $\begin{array}{l}\text { Long-sleeve sweatpants 1 } \\
\text { Blusa de moletom }\end{array}$ & 0.34 & $\square$ Ancke-length Socks 1 Meias esportivas & 0.02 \\
\hline$\square$ Sleeveless vest 1 Colete sem mangas & 0.13 & $\square$ Boots 1 Botas & 0.10 \\
\hline \begin{tabular}{l}
$\square$ Jeans 1 Calça Jeans \\
\hline Straight trousers (thin) 1 Calça Social
\end{tabular} & 0.24 & $\square$ Tennis/Shoes 1 Tênis/Sapato & 0.02 \\
\hline$\square$ Sweatpants 1 Calça de moletom & 0.15 & $\square$ long sleeve shirt 1 Sandália & 0.02 \\
\hline
\end{tabular}

72 De Vecchi, R.; Lamberts, R.; Candido, C. M. 
Figure 1 - Distribution of the operative temperature during the field experiments

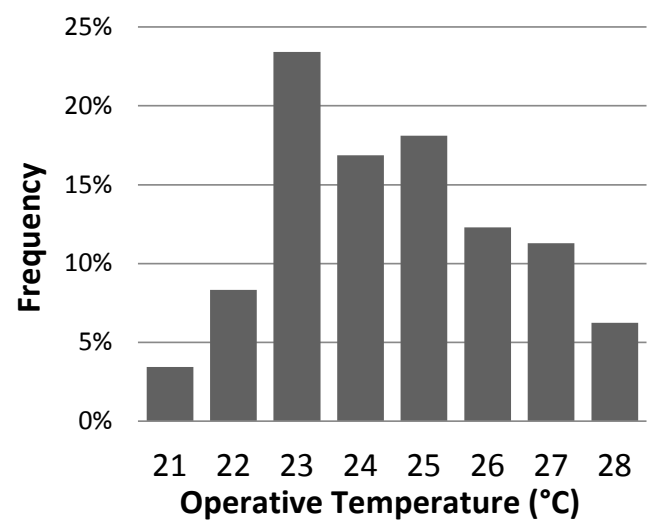

Figure 2 - Data frequency according with the seasons of the year

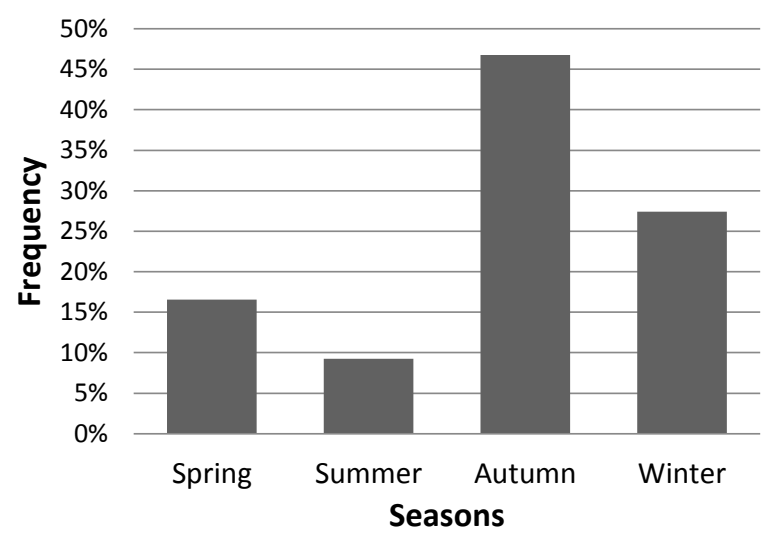

Table 4 - Collected votes separated by age and gender profile per building type

\begin{tabular}{|c|c|c|c|c|c|c|c|c|}
\hline & \multicolumn{2}{|c|}{ Age $\leq \mathbf{3 0}$} & \multicolumn{2}{|c|}{$31 \leq$ age $\leq 50$} & \multicolumn{2}{|c|}{ Age $\geq 51$} & \multirow{2}{*}{$\begin{array}{c}\text { Total } \\
(\%)\end{array}$} & \multirow{2}{*}{$\begin{array}{c}\text { Sample } \\
\text { (n) }\end{array}$} \\
\hline & Males & Females & Males & Females & Males & Females & & \\
\hline Тур & 169 & 155 & 433 & 264 & 194 & 59 & $25.4 \%$ & \\
\hline Type 2 building & 156 & 178 & 370 & 467 & 182 & 118 & $29.2 \%$ & 5,036 \\
\hline Type 3 building & 1,046 & 1,165 & 36 & 44 & 0 & 0 & $45.4 \%$ & \\
\hline
\end{tabular}

Results in Figure 3 show that thermal comfort votes indicated a $80 \%$ satisfaction reported by building occupants when exposed to operative temperatures spanning from $21^{\circ} \mathrm{C}$ to $26^{\circ} \mathrm{C}$ in all building types investigated here, suggesting a worthy ratio between occupants clothing and experienced thermal conditions. In type 1 building, operative temperature has not exceeded the range between $22^{\circ} \mathrm{C}$ and $24^{\circ} \mathrm{C}$ due to the tight temperature control observed in the HVAC system. Based on these results, comfort interval was assumed between $21^{\circ} \mathrm{C}$ and $26^{\circ} \mathrm{C}$, and data beyond this range were rejected on further analysis.

\section{Seasonal and ventilation strategy impact on clo values}

Figure 4 shows the frequency of clo values observed during different seasons of the year. Not surprisingly, occupants' clo values were strongly influenced by season - values higher than 0.9 clo occurred most frequently in winter, while $0.3-0.5$ clo were registered during summer. Apart from the two well-defined seasons (summer and winter), results from autumn and spring show a strong fluctuation in clo values $(0.3-1.0$ clo $)$, which matches the characteristically variability in the outdoor weather observed during these seasons. Similar results were reported by Morgan and de Dear (2003), and Kwon and Choi (2012). 
The seasonal variability observed on the average clo values worn by subjects became clearer by analyzing this data in combination with operative temperature values measured indoors for all building types. Figure 5 shows that clo values observed in winter were statistically significant and occupants adopted approximately 0.2 clo higher than those observed during autumn. A greater difference was observed in clo values worn by people during summer and winter ( 0.75 clo vs. 0.48 clo respectively) while during spring and autumn presented a more constant value of 0.60 .

These observed differences on occupants' clothing, during the four seasons, could be directly related to the thermal conditions delivered indoor by each building type investigated here. The same way that outdoor weather influences our choice of clothing, the thermal conditions people expect to be exposed indoors may also play a role here which in turn may or may not be linked to the outdoor weather for instance subjects may be wearing a cardigan inside of an office building in the middle of summer. Figure 6 shows the outcomes for all buildings type: (a) a fully air-conditioned commercial building (type 1);

(b) two mixed-mode government buildings (type 2); and

(c) university classroom with a mixed-mode system (type 3 ) binned by operative temperature values.

The air-conditioning was used in $28 \%$ of the measured period in mixed-mode buildings (type 2 buildings) while in classrooms (type 3 buildings) the same usage achieved 52\%. Type 1 and 2 buildings - both office environments, the clo values varied very little while in Type 3 buildings a bigger variation was observed. This can be explained by the dress code observed in Type 1 and 2 buildings and also the age profile of the sample. The mild variation in clo values in type 2 and the higher variability in type 3 suggest that occupants may be taking advantage of the adaptive opportunities available to them in these mixedmode environments (changing the clothing, opening/closing windows or even turning on/off AC units).

Figure 3 - Frequency of thermal comfort votes according with the three types of building and binned operative temperature $\left({ }^{\circ} \mathrm{C}\right)$

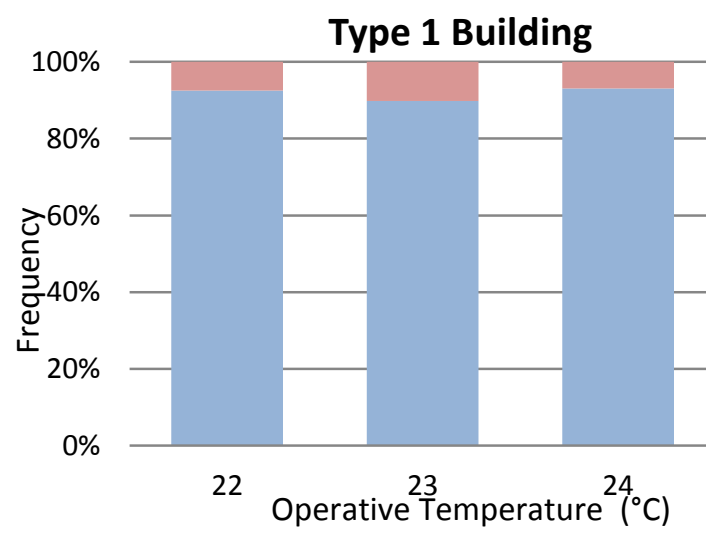

(a)

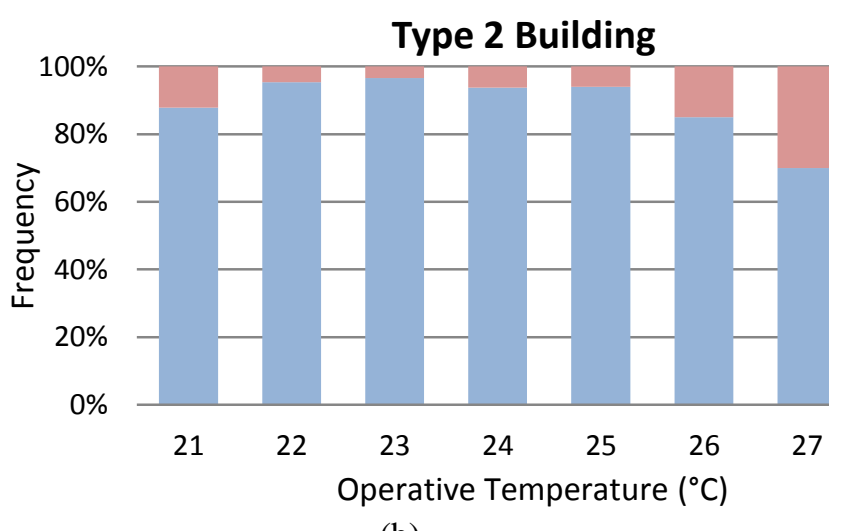

(b)

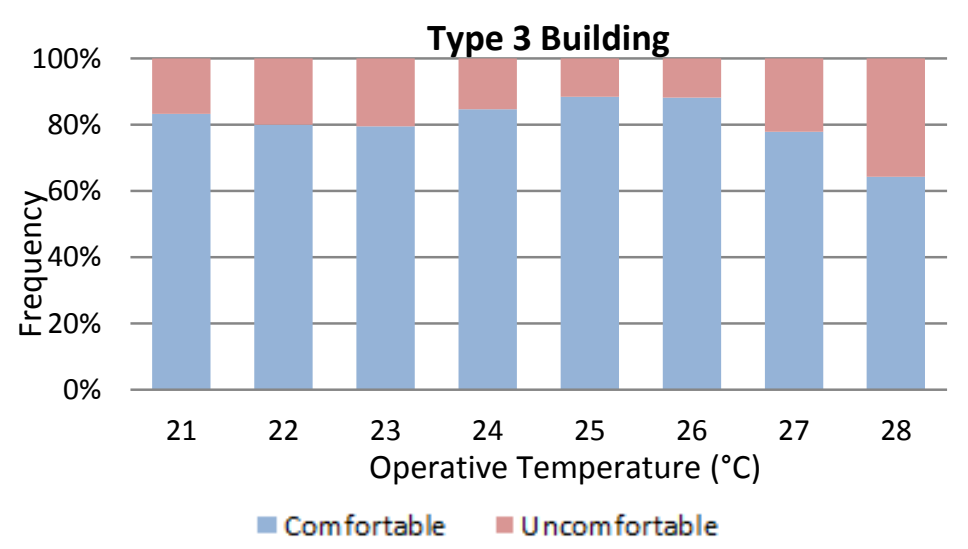

(c)

74 De Vecchi, R.; Lamberts, R.; Candido, C. M. 
Figure 4 - Frequency of observed clothing insulation according with the four annual seasons

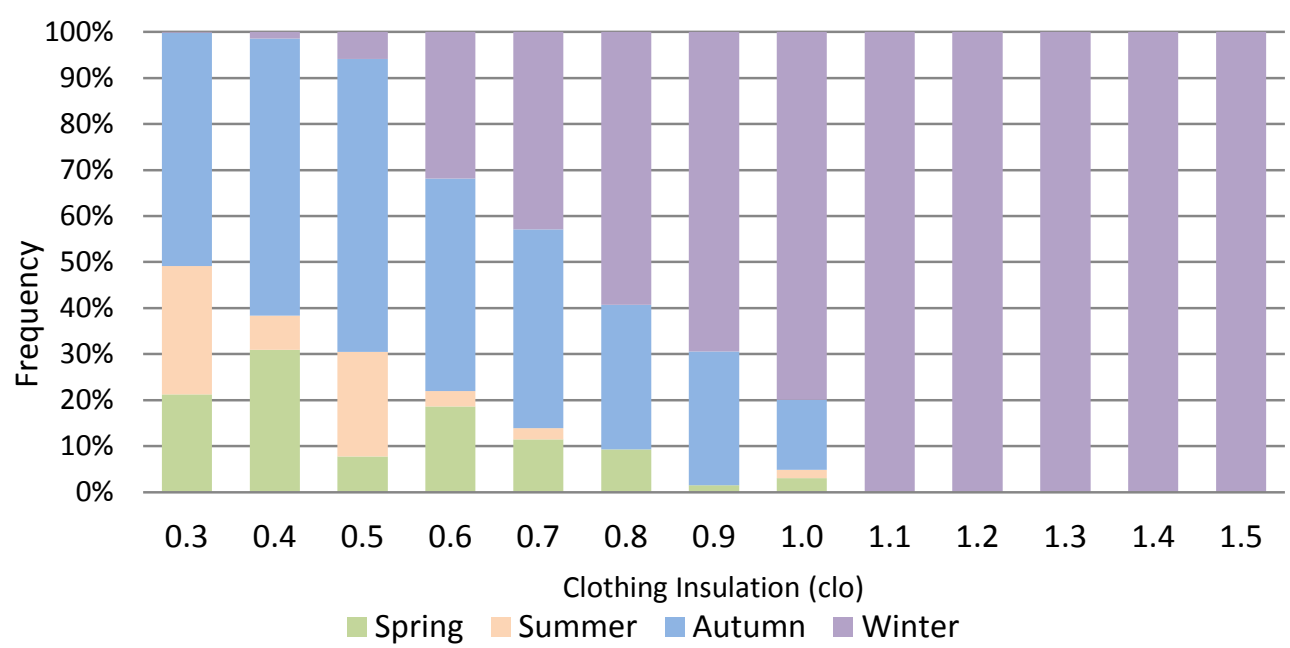

Figure 5 - Clothing average associated with the annual seasons and operative temperature $\left({ }^{\circ} \mathrm{C}\right)$

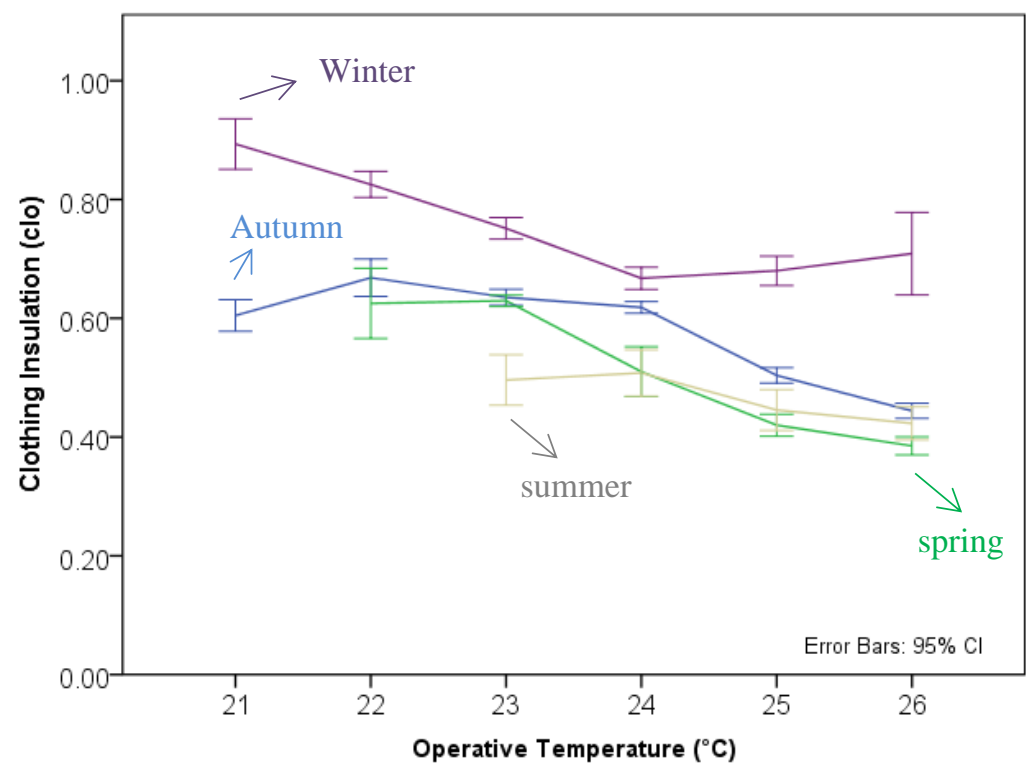

Figure 6 - Distribution of clothing values according with the operative temperature in the building type 1 (a), type 2 (b) and type 3 (c)

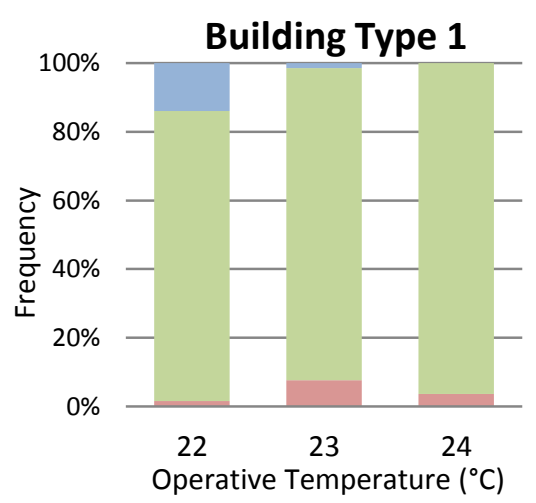

(a)

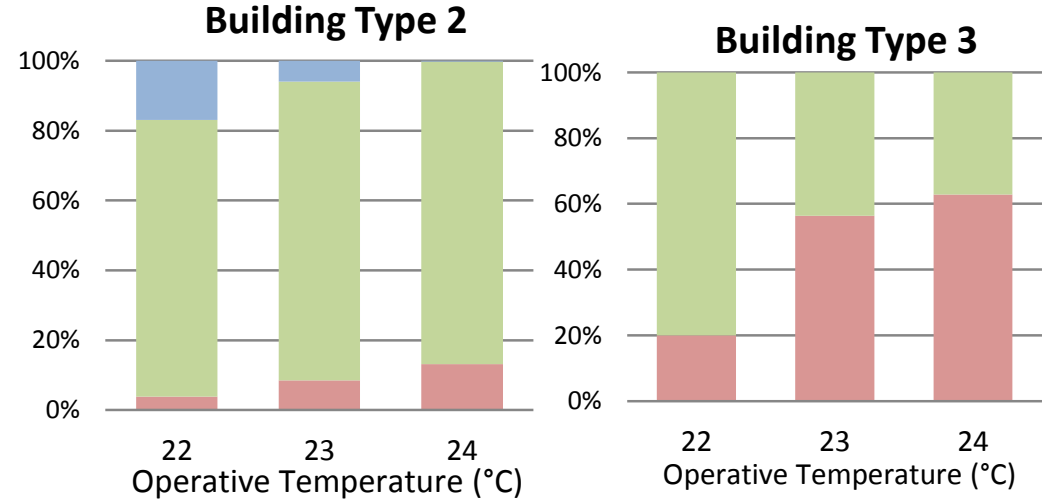

(c)

$\pm \mathrm{clo}<0.5 \quad 0.5<\mathrm{clo}<1.0 \quad \mathrm{~m}=\mathrm{clo}>1.0$ 
Figure 7 shows the average values of clothing insulation for each type of building binned by operative temperature values. In type 3 building, where occupants wore more casual garments and no dress code is required, clothing insulation is substantially smaller than others buildings. Comparing the results from the office buildings (1 and 2) it is possible to observe that clothing average values were statistically different and

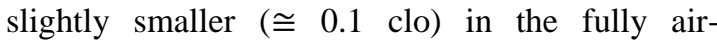
conditioning building. Even though small, this difference shouldn't be completely ignored results reported by De Carli et al. (2007) indicate that even small difference in clo value of 0.1 in air-conditioning buildings may be sufficient to impact on occupants' comfort (and the PMV/PPD calculations).

\section{Gender and age groups differences in clo values}

The frequency of each clo value bin ranging from 0.3 to 1.5 for male and female occupants were illustrated in Figure 8. It is worth mentioning the difference of clo value distribution between male and females. For males, there is a much higher frequency of clo value in the $0.6 \mathrm{bin}$, which represents a typical ensemble of long trousers and a long (short)-sleeve shirt in the work environment. As for females, the frequencies are more spread out between different bins, meaning that there are more variations in terms of what they are wearing for work. These differences were also observed when each type of building was analysed separately. Females presented a higher value of clo in all occasions ( 0.04 higher in HVAC buildings and 0.06 higher in mixed-mode buildings and classrooms).

Although the dressing code in the work environment is similar between different genders, Figure 9 does show a much higher variation of women's clo values than men's. Figure 10 also reports a higher SD value for females than males, which corroborate with the findings in Morgan and de Dear (2003).

Figure 10 presents the average clo value along with its $95 \%$ confidence intervals across a range of operative temperatures for males and females. Except for the operative temperatures of $21^{\circ} \mathrm{C}$ and $24^{\circ} \mathrm{C}$ where the two confidence intervals overlap, other operative temperatures have observed significantly different clo values $(p<0.05)$ between males and females, with females generally 0.1 to 0.2 higher than males. Theses results may be driven by the higher cold sensitivity that women usually demonstrate, as reported in several comfort studies (NAKANO; TANABE; KIMURA, 2002; MORGAN; DE DEAR, 2003; KINGMA; FRIJNS; VAN MARKEN LICHTENBELT, 2012; SCHELLEN et al., 2012). The higher variability in women's dresses that are discussed previously could also contribute to this difference. According to Morgan and de Dear (2003), men tend to follow a more fixed dressing code than women do, regardless of outdoor temperatures.

\section{Figure 7 - Clothing average associated with the type of buildings and the operative temperature $\left({ }^{\circ} \mathrm{C}\right)$}

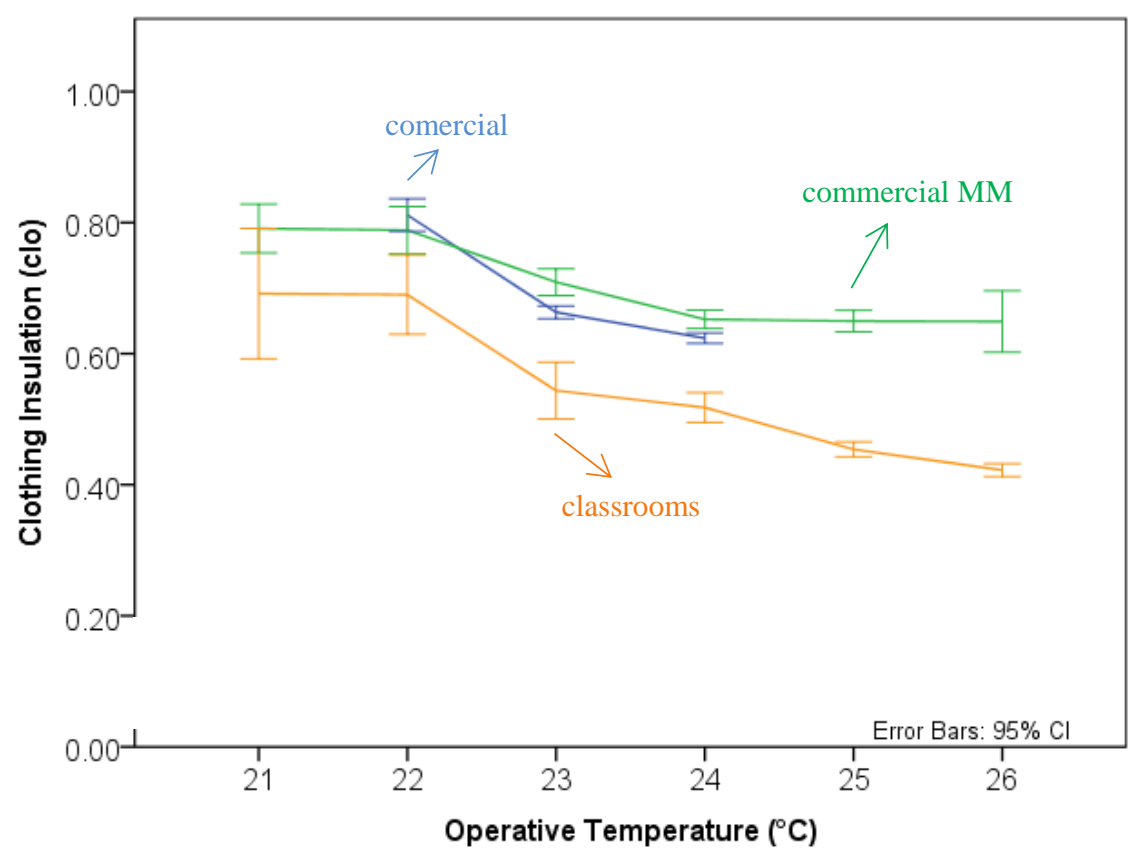

76 De Vecchi, R.; Lamberts, R.; Candido, C. M. 
Figure 8 - Clothing distribution according with the occupants' gender

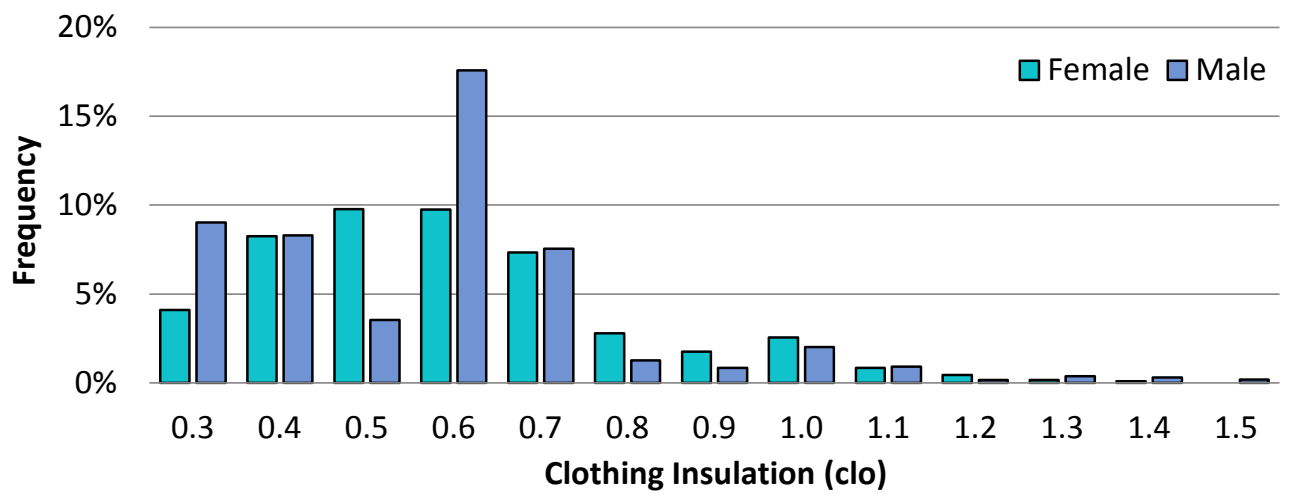

Figure 9 - Clothing distribution according with the business occupants and their gender

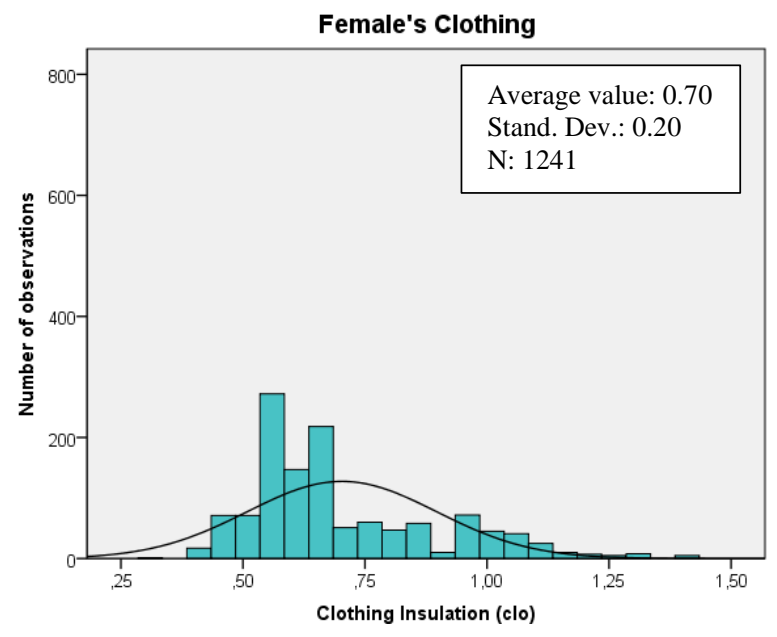

(a) Female's clothing

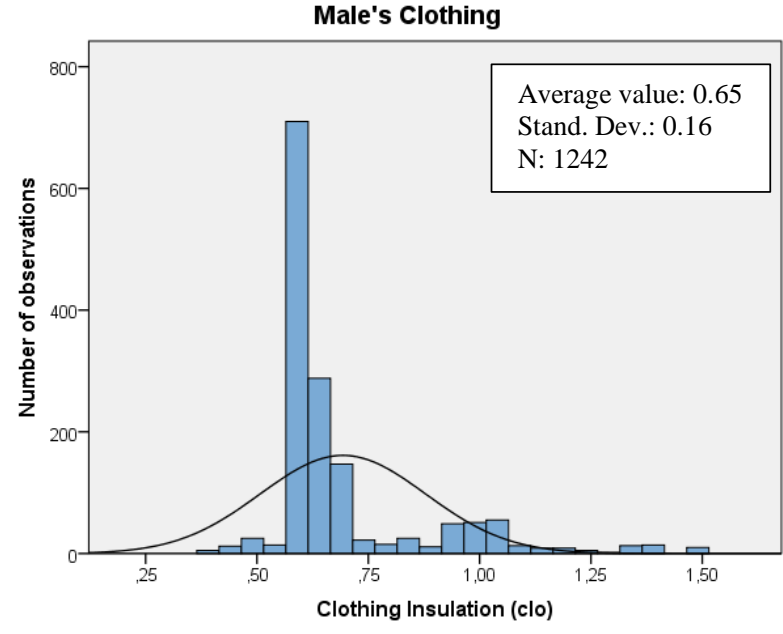

(b) Male's clothing

Figure 10 - Clothing average associated with the occupants' gender and the operative temperature $\left({ }^{\circ} \mathrm{C}\right)$

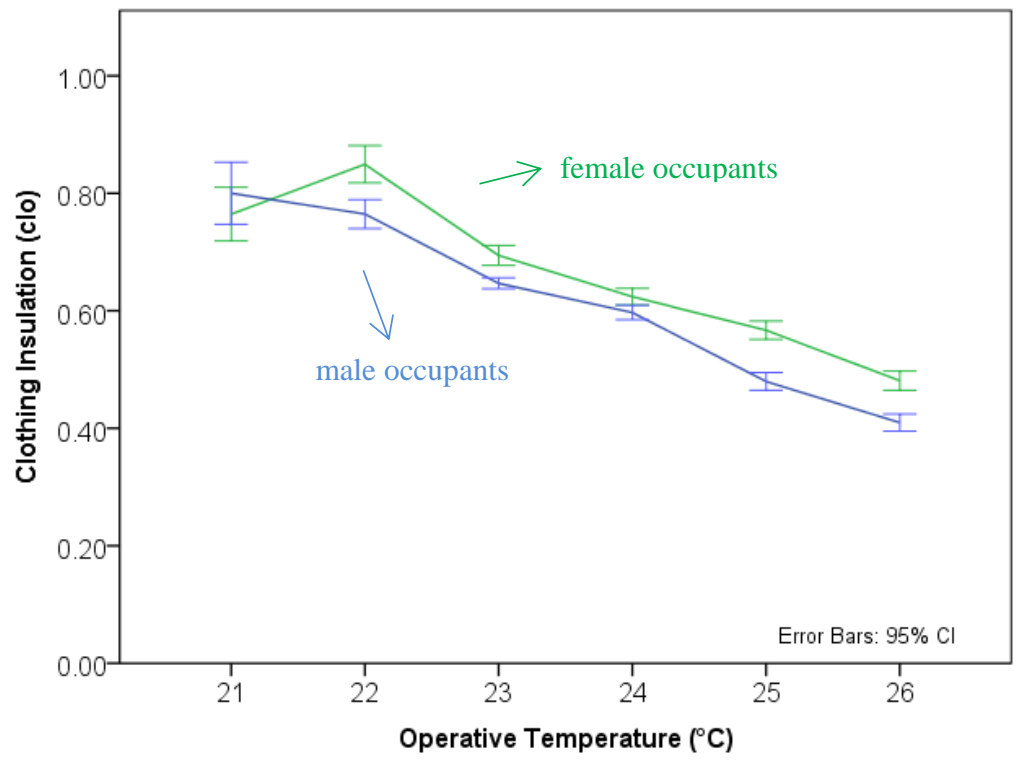


Another aspect regarding clo values is the intergenerational differences. Figure 11 shows the distribution of clo value frequencies according to different age groups: group 1, younger than 30 years old; group 2, between 31 and 50 years; and group 3 older than 51 years. It is clear that younger occupants have a higher frequency of clo values below 0.7 , while occupants from group 2 and 3 generally have higher frequencies in clo value around 0.6 and 0.7 . This difference in clothing insulation can also be observed in Figure 12, which associates the average clo values with operative temperatures.

The youngest occupants presented the lowest levels of clothing insulation in the operative temperature range between 24 and $26^{\circ} \mathrm{C}$, while the eldest group tend to have the heaviest clothing. However, it should be noted that there is no difference in clo values between different age groups. Differences over the age groups can also be linked to physiological differences such as metabolism. Also, no difference was observed between age groups among the different types of buildings. However, what needs to be pointed out is that all of the maximum observed clothing values occurred in the age groups 2 and 3 (clothing values were 0.15 higher among the maximum values in the age groups 2 and 3 compared to 1 ). De Vecchi (2015) has reported significant differences between the preferred temperature of the same age groups across the SET* interval of $22^{\circ} \mathrm{C}$ to $26^{\circ} \mathrm{C}$.

\section{Figure 11 - Clothing distribution according with the occupants' age}

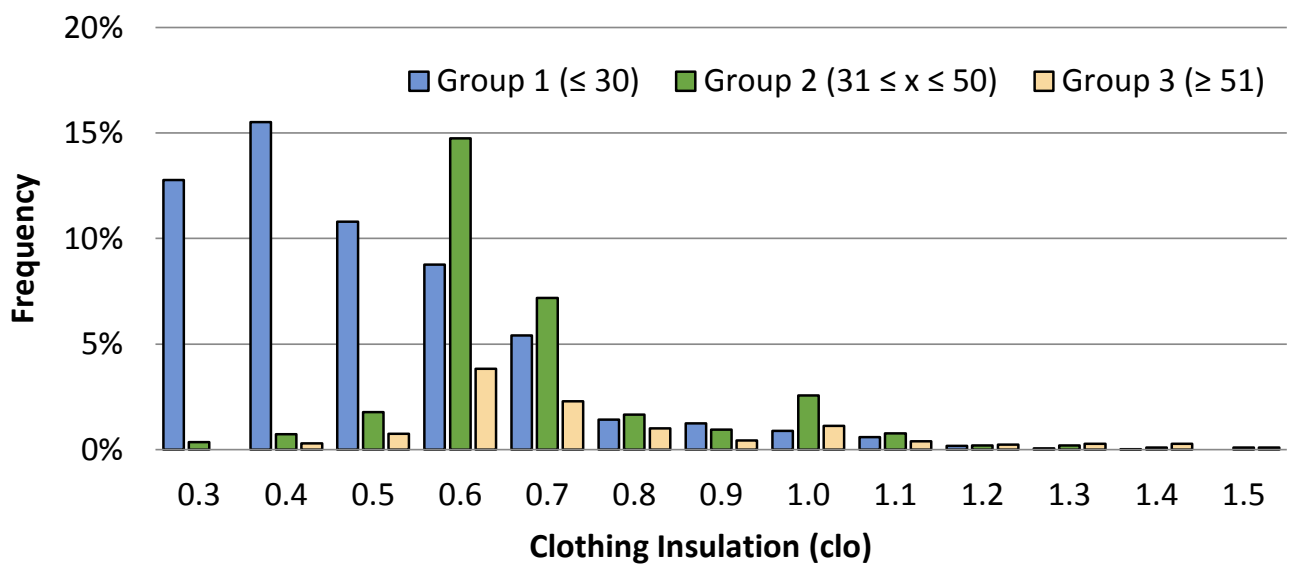

Figure 12 - Clothing average associated with the annual seasons and the operative temperature $\left({ }^{\circ} \mathrm{C}\right)$

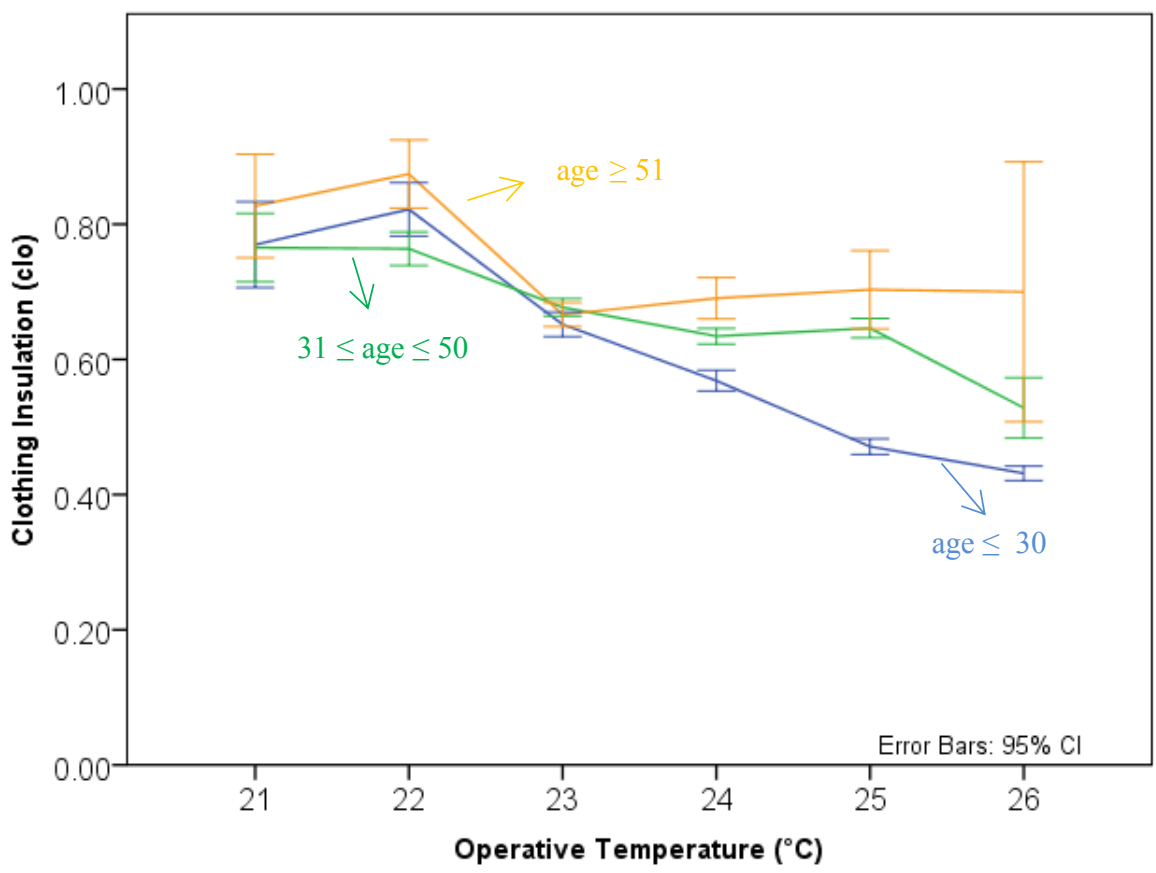

78 De Vecchi, R.; Lamberts, R.; Candido, C. M. 


\section{Conclusions}

Based on observations from field studies conducted in a Brazilian temperate and humid climate, this paper presented a preliminary investigation in the subjective issues that could have impact on clothing insulation. The results suggest that clothing values chosen by occupants were related to Brazil's climate and culture, their anthropometric characteristics and the indoor climatic regimes in different types of buildings. Based on the results found in this study, there is no doubt that season has a huge impact on building occupants' clothing insulation during the study. All through the spring days $(n=833)$ the average clo value of building occupants was 0.54 ; in the summer it was $0.42(\mathrm{n}=466)$, during the autumn it was $0.53(\mathrm{n}=833)$ and in winter it was 0.78 $(n=1382)$. Even with the same operative temperature inside buildings, clothing values were different. The average values found in this study are marginally different from the suggested values in international standards $(0.5$ for summer and 1.0 for winter).

For classrooms and office work environments, there are different clo values observed even at the same temperature. As much as both of analyzed kinds of buildings can be classified as prolonged exposure environments, a large difference between student's expectations about their daily activities could have an impact on the choices of clothing, as well as the nonexistence of a corporate dress code. These assumptions possibly led them to use lower levels of clothing than office workers. The clothing behavior was also compared across the commercial buildings with different cooling systems, and it was observed a slightly higher variability on clothing insulation in the mixed-mode building (a 0.04 difference on standard deviation), which also represented the model with higher Pearson's coefficient (35\% compared to $26 \%$ ). These results highlight the impact of indoor climate on clothing insulation levels and possible implications for the energy consumption. Wearing heavier clothes during winter and lighter clothes during summer can reduce the heating and cooling loads; mixedmode buildings can serve as an example of more energy efficient buildings and more comfortable environments - especially when controlled by occupants.

Back to the dress code issue, differences between "casual clothing" and "business clothing" environments represented in this study by students and office workers raise another discussion about initiatives such as Cool Biz in Japan and the "notflexibilities" of the corporate dress code applied in large and hot urban centers of Brazil such as
Florianópolis. On these assumptions, female occupants may be privileged, given the flexibility they can have on day-to-day corporate clothing verified in this study. However, due to their higher sensitivity to cold environments and differences on metabolic rate discussed in previous papers, women might be dealing with the over cooling inside buildings (or, just with the unnecessary use of air conditioning in mixed-mode environments) through warmer clothes, while men have relatively fixed dress code.

Whether the intergenerational difference represents an important factor to be considered in dress patterns is still under question; Yet, the results from this paper call for a further examination on the thermal comfort impact of fixed and liberal dress codes during the hottest days.

\section{References}

\section{AMERICAN SOCIETY OF HEATING REFRIGERATING AND AIR-CONDITIONING ENGINEERS. ASHRAE Handbook}

Fundamentals. Atlanta, 2013b. chap. 8.

AMERICAN SOCIETY OF HEATING REFRIGERATING AND AIR-CONDITIONING ENGINEERS. Standard 55: thermal environmental conditions for human occupancy. Atlanta, 2013a.

ANDREASI, W. A.; LAMBERTS, R.; CANDIDO, C. Thermal Acceptability Assessment in Buildings Located in Hot and Humid Regions in Brazil. Building and Environment, v. 45, n. 5, p. 1225-1232, 2010.

CANDIDO, C. et al. Air Movement Acceptability Limits and Thermal Comfort in Brazil's Hot Humid Climate Zone. Building and

Environment, v. 45, n. 1, p. 222-229, 2010.

CANDIDO, C. et al. Aplicabilidade dos Limites da Velocidade do Ar Para Efeito de Conforto Térmico em Climas Quentes e Úmidos. Ambiente Construído, Porto Alegre, v. 10, n. 4, p. 59-68, out./dez. 2011.

CHUN, C. et al. Thermal Diary: connecting temperature history to indoor comfort. Building and Environment, v. 43, n. 5, p. 877-885, 2008.

DE CARLI, M. et al. People's Clothing Behaviour According to External Weather and Indoor Environment. Building and Environment, v. 42, n. 12, p. 3965-3973, 2007.

DE DEAR, R.; BRAGER, G.; COOPER, D. Developing an Adaptive Model of Thermal Comfort and Preference: Final Report on ASHRAE RP - 884. Sydney: MRL, 1997. 
DE VECCHI, R. Condições de Conforto Térmico e Aceitabilidade da Velocidade do Ar em Salas de Aula Com Ventiladores de Teto Para o Clima de Florianópolis/SC. Florianópolis, 2011. Dissertação (Mestrado em Engenharia Civil) - Departamento de Engenharia Civil, Universidade Federal de Santa Catarina, Florianópolis, 2011.

DE VECCHI, R. Avaliação de Conforto térmIco em Edificações Comerciais que Operam Sob Sistemas Mistos de Condicionamento Ambiental em Clima temPerado e Úmido. Florianópolis, 2015. Tese (Doutorado em Engenharia Civil) - Departamento de Engenharia Civil, Universidade Federal de Santa Catarina, Florianópolis, 2015.

DE VECCHI, R.; CANDIDO, C.; LAMBERTS, R. Thermal History and Comfort in a Brazilian Subtropical Climate: a "cool" addiction hypothesis. Ambiente Construído, Porto Alegre, v. 16, n. 1, p. 7-20, jan./mar. 2016.

FANGER, P. O. Thermal Comfort: analysis and applications in environmental engineering. Copenhagen: Darlish Techinical Press, 1970.

GOULART, S.; LAMBERTS, R.; FIRMINO, S. Dados Climáticos Para Projeto e Avaliação Energética de Edificações Para 14 Cidades Brasileiras. Florianópolis: PROCEL/Núcleo de Pesquisa em Construção Civil, UFSC, 1998.

HAVENITH, G.; HOLMÉR, I.; PARSONS, K. Personal Factors in Thermal Comfort Assessment: Clothing Properties and Metabolic Heat Production. Energy and Buildings, v. 34, n. 6, p. 581-591, 2002.

INDRAGANTI, M.; OOKA, R.; RIJAL, H. B. Thermal Comfort in Offices in Summer: findings from a field study under the "setsuden" conditions in Tokyo, Japan. Building and Environment, v. 61, n. 114-132, 2013.

KINGMA, B. R.; FRIJNS, A.; VAN MARKEN LICHTENBELT, W. The Thermoneutral Zone: implications for metabolic studies. Frontiers in Bioscience, v. 4, p. 1975-1985, 2012.

KRÜGER, E. L.; ROSSI, F. A. Effect of Personal and Microclimatic Variables on Observed Thermal Sensation From a Field Study in Southern Brazil. Building and Environment, v. 46, n. 3, p. 690697, 2011.

KWON, J.; CHOI, J. The Relationship Between Environmental Temperature and Clothing Insulation Across a Year. International journal of biometeorology, v. 56, n. 5, p. 887-93, sep. 2012.
LABAKI, L. C. et al. Conforto Térmico em Espaços Públicos de Passagem: estudos em ruas de pedestres no estado de São Paulo. Ambiente Construído, Porto Alegre, v. 12, n. 1, p. 167-183, jan./mar. 2012.

LAZAROTTO, N.; SANTOS, J. C. P. Avaliação do Conforto Térmico de Estudantes do Ensino Fundamental na Região Noroeste do RS. In: ENCONTRO NACIONAL NO AMBIENTE CONSTRUÍDo, 9., Ouro Preto, 2007.

Anais...Ouro Preto, 2007.

MONTEIRO, L. M.; ALUCCI, M. P. Modelo Adaptativo de Conforto Para Avaliação in loco de Espaços Urbanos Abertos. Ambiente Construído, Porto Alegre, v. 12, n. 1, p. 61-79, jan./mar. 2012.

MORGAN, C.; DE DEAR, R. Weather, Clothing and Thermal Adaptation to Indoor Climate. Climate Research, v. 24, p. 267-284, 2003.

NAKANO, J.; TANABE, S.; KIMURA, K. Differences in Perception of Indoor Environment Between Japanese and Non-Japanese Workers. Energy and Buildings, v. 34, n. 6, p. 615-621, 2002.

ROSSI, F. A.; KRÜGER, E. L.; BRÖDE, P. Definição de Faixas de Conforto e Desconforto Térmico Para Espaços Abertos em Curitiba, PR, Com o Índice UTCI. Ambiente Construído, Porto Alegre, v. 12, n. 1, p. 41-59, jan./mar. 2012.

SCHELLEN, L. et al. The Influence of Local Effects on Thermal Sensation Under Non-Uniform Environmental Conditions-Gender Differences in Thermophysiology, Thermal Comfort and Productivity During Convective and Radiant Cooling. Physiology \& behavior, v. 107, n. 2, p. 252-61, 2012.

SCHIAVON, S.; LEE, K. H. Dynamic Predictive Clothing Insulation Models Based on Outdoor Air and Indoor Operative Temperatures. Building and Environment, v. 59, p. 250-260, 2013.

TANABE, S.; IWAHASHI, Y.; TSUSHIMA, S. Thermal Comfort and Productivity in Offices Under Mandatory Electricity Savings After Great East Japan Earthquake. In: WINDSOR CONFERENCE: THE CHANGING CONTEXT OF COMFORT IN AN UNPREDICTABLE WORLD, 7., Cumberland Lodge, 2012. Proceedings... Cumberland Lodge, 2012.

XAVIER, A. A. P.; LAMBERTS, R. Indices of Thermal Comfort Developed From Field Survey in Brazil. ASHRAE Transactions, v. 106, p. 45-58, 2000. 


\section{Acknowledgements}

This project was supported by the Brazilian Federal Governments' $\mathrm{CNPq}$ and CAPES. The authors would like to thank everyone involved in the field experiment, and Ms. Fan (Jessica) Zhang from The University of Sydney's IEQ Lab.

\section{Renata De Vecchi}

Departamento de Engenharia Civil | Universidade Federal de Santa Catarina | Rua João Pio Duarte Silva, 241, Córrego Grande, Campus Universitário, Trindade | Caixa Postal 476 | Florianópolis - SC - Brasil | CEP 88040-900 | Tel.: (48) 3721-5185 |

E-mail: redevecchi@gmail.com

\section{Roberto Lamberts}

Departamento de Engenharia Civil | Universidade Federal de Santa Catarina | Tel.: (48) 3721-5191 | E-mail: roberto.lamberts@ufsc.br

\section{Christhina Maria Candido}

Faculty of Architecture, Design and Planning | The University of Sydney | Wilkinson bd (G04), Room 587, Darlington | Sydney - Austrália | 2006 | Tel: (2) 9351-3206 | E-mail: christhina.candido@sydney.edu.au

\section{Revista Ambiente Construído}

Associação Nacional de Tecnologia do Ambiente Construído

Av. Osvaldo Aranha, $99-3^{\circ}$ andar, Centro

Porto Alegre - RS - Brasil

$$
\text { CEP } 90035-190
$$

Telefone: +55 (51) 3308-4084

Fax: +55 (51) 3308-4054

www.seer.ufrgs.br/ambienteconstruido

E-mail: ambienteconstruido@ufrgs.br 